\title{
Territorial impact of the COVID-19 pandemic in Galicia (Spain): a geographical approach
}

Impacto territorial de la pandemia COVID-19

en Galicia (España): un enfoque geográfico

\section{Ángel Miramontes Carballada}

angel.miramontes@usc.es

Departamento de Xeografía

Universidade de Santiago de Compostela (España)

Jose Balsa-Barreiro

jobalbar@gmail.com

IDEGA (Instituto Universitario de Estudios y Desarrollo de Galicia)

Universidade de Santiago de Compostela (España)

\begin{abstract}
The coronavirus pandemic is causing a huge impact around the world. Its real magnitude presents very important regional differences, which are appreciable in the number of infected and victims in the different countries. The outbreak of the pandemic and the ignorance of the virus mean that, even today, there are many unknowns about essential aspects related to it. In this sense, geographic knowledge can help answer many questions from the territorial analysis of the data. The objective of this article will be to analyze the behavior of the coronavirus pandemic within the Spanish region of Galicia. The authors of this study propose a multiscale analysis that allows deciphering the most common propagation patterns. For this, we have high spatial resolution data that has been provided by the competent authority under confidentiality. The
\end{abstract}


results of this work allow us to represent and interpret the territorial impact of the pandemic, understanding its behavior as far as possible, allowing future dynamics to be predicted.

Key words: spatial analysis; Geographic Information System (GIS); mapping.

\section{Resumen}

La pandemia de coronavirus está causando un gran impacto en todo el mundo. Su magnitud real presenta diferencias regionales muy importantes, que son apreciables en el número de infectados y víctimas en los diferentes países. El estallido de la pandemia y el desconocimiento del virus hacen que, aún hoy, existan muchas incógnitas sobre aspectos esenciales relacionados con el mismo. En este sentido, el conocimiento geográfico puede ayudar a responder muchas preguntas a partir del análisis territorial de los datos. El objetivo de este artículo será analizar el comportamiento de la pandemia de coronavirus dentro de la región española de Galicia. Los autores de este estudio proponen un análisis multiescala que permite descifrar los patrones de propagación más comunes. Para ello, contamos con datos de alta resolución espacial que han sido facilitados por la autoridad competente bajo confidencialidad. Los resultados de este trabajo permiten representar e interpretar el impacto territorial de la pandemia, entendiendo en la medida de lo posible su comportamiento, permitiendo predecir dinámicas futuras.

Palabras clave: análisis espacial; Sistema de Información Geográfica (SIG); cartografía.

\section{Introduction}

The coronavirus disease 2019 (COVID-19) pandemic is an ongoing crisis caused by the severe acute respiratory syndrome coronavirus 2 (SARS-CoV-2). The first outbreak was detected in December 2019 in Wuhan, the capital of Hubei province, quickly followed by the rest of Hubei and all other provinces in China. In mainland China, the epidemic was largely controlled by the end of March 2020, having generated more than 80,000 cases (Chang et al., 2020; NHC, 2020; Wang et al., 2020; WHO, 2020a; The Novel Coronavirus Pneumonia Emergency Response Epidemiology Team, 2020).

Despite unprecedented national control measures, COVID-19 was not fully contained, and the disease spread to other countries. On January 31, 2020, the epidemic was recognized by the World Health Organization (WHO) as a public health emergency of international concern, and on March 11, 2020, the WHO declared the outbreak as a pandemic (WHO, 2020b). By the end of March 2020, the global death toll had exceeded 36,200, and infections rose to more than 
755,500 (BBC News, 2020). The effects of the COVID-19 pandemic have rapidly spread far beyond the health sector, encompassing the entire global economic and social fabric (Lenzen et al., 2020).

The coronavirus pandemic started hitting Europe hard, especially Italy and Spain which had more than 100,000 and 86,000 coronavirus cases respectively on March 30. In Spain, the first case was confirmed in the Canary Islands on January 31 (an English tourist), and at the end of February, multiple cases of coronavirus related to the COVID-19 outbreak in Italy were confirmed. The virus spread rapidly throughout the Spanish territory. On March 14, all Spanish provinces had already registered cases, at which time the Government of Spain declared a state of national alarm (The Lancet Public Health, 2020).

This national blockade of the population to combat the coronavirus consisted of the closure of all commercial establishments (clothing, appliances, etc.) and services (restaurants, cafeterias, etc.) except pharmacies and essential stores (food). The Spanish authorities further tightened the blockade by instructing non-essential workers to stay home and extending the blockade until midApril. Those infected with the pandemic slowed down, but it was only temporarily and continued to grow, by waves.

But unlike other European countries, Spain has the peculiarity that each of its 17 Autonomous Communities has the competences in terms of health (among others, such as education). For this reason, despite considering a series of measures at the level of the whole of Spain, each Autonomous Community "readapted" them to their needs and made certain decisions under their autonomous criteria. So with different results (Figure 1).

Therefore, the heterogeneity of the territorial behavior of the pandemic that has originated and is currently maintained in Spain is wide. Reason why, as those responsible for investigating on the behaviour of COVID-19 in Galicia, we consider it important to present and offer the methodology and results obtained from one of its parts, for other areas of Spain, Europe, and the world.

For example, within the diversity of internal restrictions within Spain, the governments of Madrid, La Rioja and the Basque Country prohibited all face-to-face teaching in their autonomous communities three days after the state of alarm. The local outbreaks forced the government of Catalonia to quarantine four Catalan municipalities before the state of alarm, on March 12, etc. In addition, the very idiosyncrasy of the Spanish has influenced, how could it be otherwise, in the spread of a COVID-19 pandemic where its spread is focused on connectivity and human relations. 
Figure 1. Incidence of COVID-19 in Spain during the first wave

(data updated on June 14, 2020)

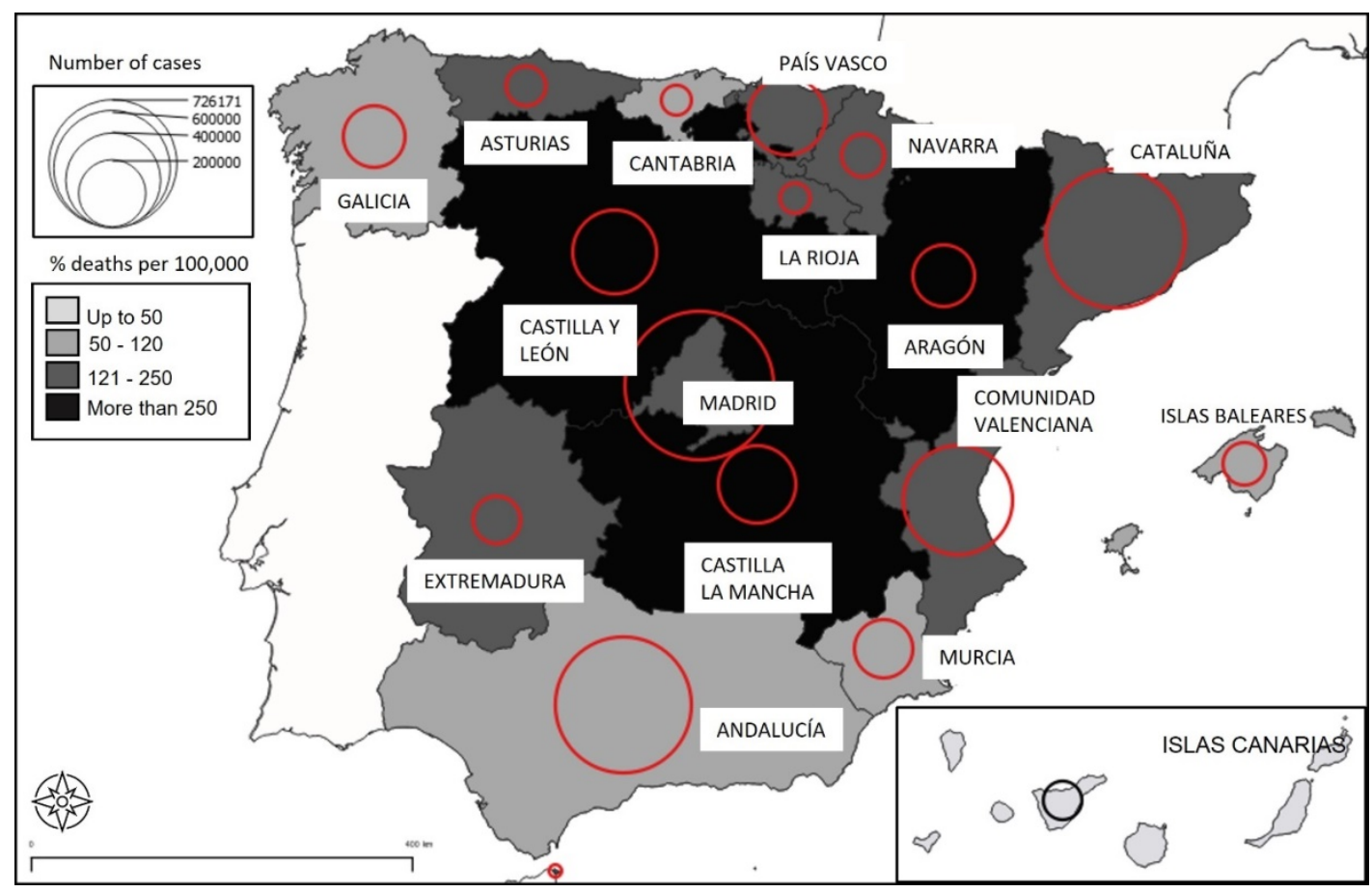

Source: authors' own elaboration from data

from National Epidemiology Center, Carlos III Health Institute (2020)

Well, the reality is that COVID-19 does not behave the same in all territories. Mainly for 2 reasons: the way of managing it was not the same and the characteristics of the territory are different (demographic and economic structure, customs, etc.). Therefore, we consider that through a spatial analysis with Geographic Information Systems (GIS) with health data, it will provide us with light on the influence of COVID-19 in Galicia.

We created some maps that were put at the service of the competent authorities in the management of the pandemic so that they could use them as they saw fit. Being a real example of the significance, that a exact mapping can have (Carballada \& Balsa-Barreiro, 2021; TriasLlimós et al., 2020; Rosenkrantz et al., 2021).

With a clear objective, the structure of the article is defined by a brief description of the relationship of Health Geography and GIS with the territorial study of pandemics throughout history. Next, an exhibition of the methodology and material used for the development of this article is made, where one of its greatest potentialities is found, such as the use of a wide and detailed database on those infected by COVID-19 with the maximum detail. As well as its 
dumping within a GIS. Next, we present some cartographic results where we show the territorial behavior that this pandemic has had in Galicia.

\section{Health geography literature and GIS}

COVID-19 requires an analysis that takes an interdisciplinary approach, and geography is one of the few disciplines that can offer a synthetic approach to the interaction between the environment and man by approaching the territory from a holistic perspective (Schnaiberg \& Gould, 1994; Turner, 2002). Other disciplines define the natural, historical, economic, and social characteristics, but geography places them in a spatial perspective analysing the territory (Pattison, 1964).

The COVID-19 pandemic is full of unknowns, and many of them have a spatial dimension that leads to understanding the phenomenon as geographic and with the potential to be mapped. Thus, from the health sciences, to interpret the COVID-19 phenomenon, they affect the need to know its spatial and temporal analysis, its geographical impact on decision-making and predict the evolution of the disease. For these reasons, the use of geospatial tools and statistics has gained special relevance with the declaration of COVID-19 as a global pandemic. It can also be a useful resource in understanding the geographic consequences and effectiveness of disease containment.

Before the arrival of COVID-19, there are many studies focused on the analysis of the territorial behaviour of infectious diseases that existed in the past. In a large part, this research was carried out from the Geography of Health. Medical geography specializes in the application of concepts, methods, and quantitative techniques to address spatial problems in diseases and medicine (Meade, 2014). Within this, the geography of health focuses on concepts and geographical categories in the population related to health. According to Kearns and Moon (2002), the geography of health has a predominantly utilitarian perspective based on the analysis of the territory.

The first works of the Geography of Health, with a structure like the current studies, date from the beginning of the 20th century. These focused on the spread of diseases at different territorial scales. Over the decades, this was integrating aspects related to demographic, social, economic, and environmental variables (Gesler \& Kearns, 2002; Graham, 2000; Wilkinson, 1996). Thus, his field of interest was broadened to issues related to inequalities, use and access to services or health policies. The current consensus establishes as the main objectives of the Geography of 
Health, to evaluate aspects such as the result of health policies, the organization of services in the health of the populations and in the development of the territory (Santana, 2005). As well as that, through GIS, it is possible to develop indicators to evaluate the spread of diseases, allowing to identify transmission dynamics (Xiong et al., 2020).

In 1694 the first maps on pest containment were developed in Italy (Koch, 2005). The value of the maps as an analysis tool to understand and follow the territorial behaviour of infectious diseases became normalized. John Snow's study from the mid-nineteenth century was considered one of the most relevant, about the importance of the spatial component on identifying the origin and spread of cholera in London, mapping water sources (Bynum, 2013). Through basic cartography and geographic analysis, it was observed how the focus of the infection came from contaminated water sources.

The importance of cartography within the geography of health has been increasing from the GIS. These systems have magnified the possibilities of visualization, analysis, and detection of disease patterns (Lyseen et al., 2014). An innovative cartography, derived from GIS, now acquires a central role in all disciplines from the analysis of the phenomena that occur in the territory (Cicalò \& Valentino, 2019).

The incorporation of massive data allows defining more accurate and reliable epidemiological models, being essential to have geospatial data that refer to spatial data sets that exceed the capacity of current computer systems (Lee and Kang, 2015). Having information with cell phone data that allows inferring mobility patterns in real time (Chen et al., 2020a; Chen et al., 2020b; Buckee et al., 2020).

In the case of COVID-19, the disease is characterized by a long incubation period, high infectivity, and difficult detection, which has contributed to the rapid outbreak and development of the epidemic. This situation has led to the development of GIS and big data technology to allow rapid responses and analysis, rapid provision of information on the dynamics of the epidemic and an understanding of the rules of its development to provide support to competent administrations to manage the pandemic (Zhou et al., 2020).

The very evolution of the tools for territorial analysis and the monitoring of infectious diseases led to an increase in the number of studies using GIS. As the works on dengue by Messina et al. (2014) who analysed the global spread of dengue from 1943 to 2013 , explained for the most part by the increase in urbanization rates and international travel. As well as Cattarino et al. (2020) who developed a high-resolution global map of the intensity of dengue transmission by 
fitting geospatial models based on the environment. Another example is found in 2015, cases of the Zika virus broke out in Brazil, and the instances grew rapidly to epidemic levels in many countries. The evolution of the Zika virus was also analyzed and it was a virus transmitted by mosquitoes that caused problems in the fetuses of pregnant women (Rodriguez-Morales, 2017).

The maps are not only used to visualize the infection, but also to make decisions regarding measures for the containment of diseases. De Kadt et al. (2020) and Gibson and Rush (2020) analysed the challenges of establishing health control measures in developing countries where there are entire neighbourhoods in extreme poverty. Kuupiel et al. (2020) analysed the accessibility of the population to malaria tests in Ghana. To do this, they evaluated aspects related to the human and physical factors of the territory, created through territorial analysis, a classification of the areas with better or worse access to services.

Today, there is a consensus to affirm that one of the most important properties of epidemics is their spatial spread (Gross et al., 2020). We can use GIS and spatial statistics to answer this, and to help mitigate the epidemic through scientific information, find spatial correlations with other variables, and identify transmission dynamics (Xiong et al., 2020).

A fundamental aspect for the study of spatial patterns of diseases is the scale and level of data aggregation. These first geographic analysis also mapped and used GIS, information at more precise administrative levels (counties, provinces, etc.), something that was to be replicated in other countries such as the United States (Dong et al., 2020; Desjardins et al., 2020), Iran (ArabMazar et al., 2020), South Korea (Rezaei et al., 2020), Brazil (Dagnino et al., 2020), Israel (Rossman et al., 2020), Italy (Giuliani et al., 2020), Spain (Orea \& Álvarez, 2020), Argentina (Buzai, 2020), Mexico (Santana Juárez, 2020), India (Saha et al., 2020) and Pakistan (Sarwar et al., 2020).

In Spain, a month after the declaration of national emergency and mandatory confinement, Orea \& Álvarez (2020) analysed by provinces the effectiveness of the COVID-19 mitigation measures decreed by the government. Also at the provincial level, but in Italy, Giuliani et al. (2020) modelled the spatial-temporal dynamics of the contagion and the victims of COVID-19. As in Spain, the local distribution is very heterogeneous. There is strong evidence that strict control measures implemented in some provinces effectively break infection cycles and limit spread to nearby areas.

We also want to emphasize that, in addition to knowing how to use a GIS and, most importantly, knowing how to read the maps that are made, data processing is essential. On the other hand, 
web map viewers are playing a very important role in disseminating and providing information about COVID-19. The most referenced viewer, the one with the most international information collected and the first to connect is from John Hopkins University (Dong et al., 2020). In addition, many created their own viewers based on Dong et al. (2020), following its web design and the online platform ArcGIS and its cartographic bases. But these virtual servers are only the beginning of how location technologies and GIS can support the fight against infectious diseases such as COVID-19 (Boulos \& Geraghty, 2020). The analytical potential of GIS comes when used as a tool that collects, explores, visualizes and analysis health data in a territorial way and reproduces cartographically (Messina et al., 2016; Smith et al., 2004; Pigot et al., 2014; Deka \& Morshed, 2018; Dudley, 2008).

Currently, there are already several reviews on COVID-19, such as the one by Tobaiqy et al. (2020) where they discussed the different therapies used in patients with COVID-19, while Pham et al., 2020 discussed the use of artificial intelligence and big data to study and mitigate the effects of the virus. From the perspective of Geography, they are not abundant, but there are cases such as Ivan Franch-Pardo et al. (2020), where different works that deal with the geographical phenomena of COVID-19 were reviewed that should inspire new reflections in readers and help connect themes and tools.

Guan et al. (2020) carried out a spatial analysis of the COVID-19 by using GIS tools. For that, they extracted data from COVID-19 patients confirmed by Chinese hospitals until January 29, 2020 and proceeded to characterize the patient's profile: mean age, sex, symptoms, and their spatial-temporal characteristics, that is, identification of the rapid spread of the disease in mainland China, distribution of patients by province, characteristics between Wuhan residents and non-Wuhan residents who visited the city or had contact with citizens there. The work is important because the early date of its publication (February 28) allowed to define with greater precision the clinical characteristics of the affected patients. Also in China, at approximately the same time, we found other studies focused on the analysis of spatial-temporal models (Chen et al., 2020b; Huang et al, 2020; Gross et al., 2020; Zhang et al., 2020; Tang et al., 2020; Su et al., 2020).

Zhou et al. (2020) note that GIS has played a key role in rapidly aggregating big data from multiple sources, rapidly visualizing epidemic information, spatially tracking confirmed cases, predicting regional transmission, spatially segregating epidemic risk and level of disease, 
prevention, balance and manage the supply and demand of material resources and social orientation.

\section{Material and methodology}

This study helped inform the debate on the management response to a pandemic. Specifically, developing a territorial analysis methodology to identify the geographic behavior of the pandemic in Galicia.

We focus on the first wave, which is unadulterated, verified and highly detailed data after a confidentiality signature. We analyze and map fine-grained health data associated with COVID-19 in this region. Our data contains individual and precise information on each infected person, including their physical address. These data allow a very precise and detailed estimate of the actual spread of the virus in this territory. This information was provided to understand the spatial dynamics and impact of the pandemic, to predict its future behaviour and be able to anticipate always adapting the appropriate decisions.

In fact, our maps were used as a fundamental tool to control the pandemic and evaluate subsequent measurements, allowing us to identify spatial patterns of the virus. For this, we develop various strategies for displaying and mapping the data. A series of aspects of interest are raised, including multiscale analysis, data aggregation or the responsible use of data.

The way in which the information is represented should serve as the basis for the integration of multidisciplinary work teams, not only doctors but also from other disciplines, which for the most part have no experience in cartographic visualization. The review, analysis and interpretation of these maps should serve for making informed decisions by policymakers and authorities.

This data set contains information related to all the individual cases reported during the first wave of the pandemic, which ranges from March 1 to July 15, 2020. This information was officially transmitted to us by the Galician Health Service (SERGAS), the health authority of this region.

This dataset, initially 11,070 records, includes data related to each patient, such as main data, place of residence and physical address, and some relevant time data that allow checking a complete follow-up of the disease for each reported case (i.e. admission / death at home / hospital). Knowing that most of the mobility was restricted during the confinement, the tracking of cases and outbreaks may be limited in a spatial-temporal way because the health authorities recorded dates related to the first symptoms and the results of the tests. The official address of 
each reported case allows us to obtain a very precise graph of the real spatial behavior of the virus.

The raw dataset was initially checked for inconsistencies. The dataset was prepared and cleaned by removing duplicates. We also remove all false positives, as well as all cases with no addresses that are impossible to locate. In summary, 581 records were deleted. After that, we standardize the formats for the rest of the records. All the study and cartographic representations are carried out with ESRI technology (ArcGIS Pro and ArcGIS Online). The different extensions provided by the software allowed us to make representations by quartiles, densities and maps of mobility flows. They are not very sophisticated cartographic representations, but they are no less significant and key to approaching the territorial behavior that the pandemic has had in Galicia. Finally, a complete dataset consisting of 10,583 records was correctly geolocated on a map. This geographic dataset is the basis for the mapping work presented in the results section.

\section{Case study}

The Galicia region is located in the northwest of Spain. Its surface covers $29,575 \mathrm{~km}^{2}$ and has more than 2.7 million inhabitants. Its population density is 91.4 inhabitants per square Kilometre, only two points lower than the average in Spain. Administratively, the region is divided into 313 municipalities distributed in 4 provinces (Figure 1a). The two provinces located further to the west concentrate most of the population, reaching average densities above 140.9 in A Coruña and 209.7 inhabitants per square Kilometre in Pontevedra (INE, 2021)

Increasing levels of urbanization occurred from 1960 to 1980 and rural depopulation has contributed to a spatial concentration in some areas of this region. Today, most of the population, economic activity and political power are concentrated in a very small number of cities (LoisGonzález, 2004). The most important ones are found along the Atlantic Axis, which is drawn by the high-capacity highway (AP-9) from north to south of the region. This axis connects the cities of Ferrol, A Coruña, Santiago, Pontevedra and Vigo within this region. The most important cities are Vigo and A Coruña, with about 300,000 inhabitants each. Outside this axis, we find two cities: Lugo and Ourense. These concentrate most of the economic activity in their respective provinces and both have about 100,000 people (Figure 2). 
Figure 2. Location of Galicia in Spain and its territorial distribution

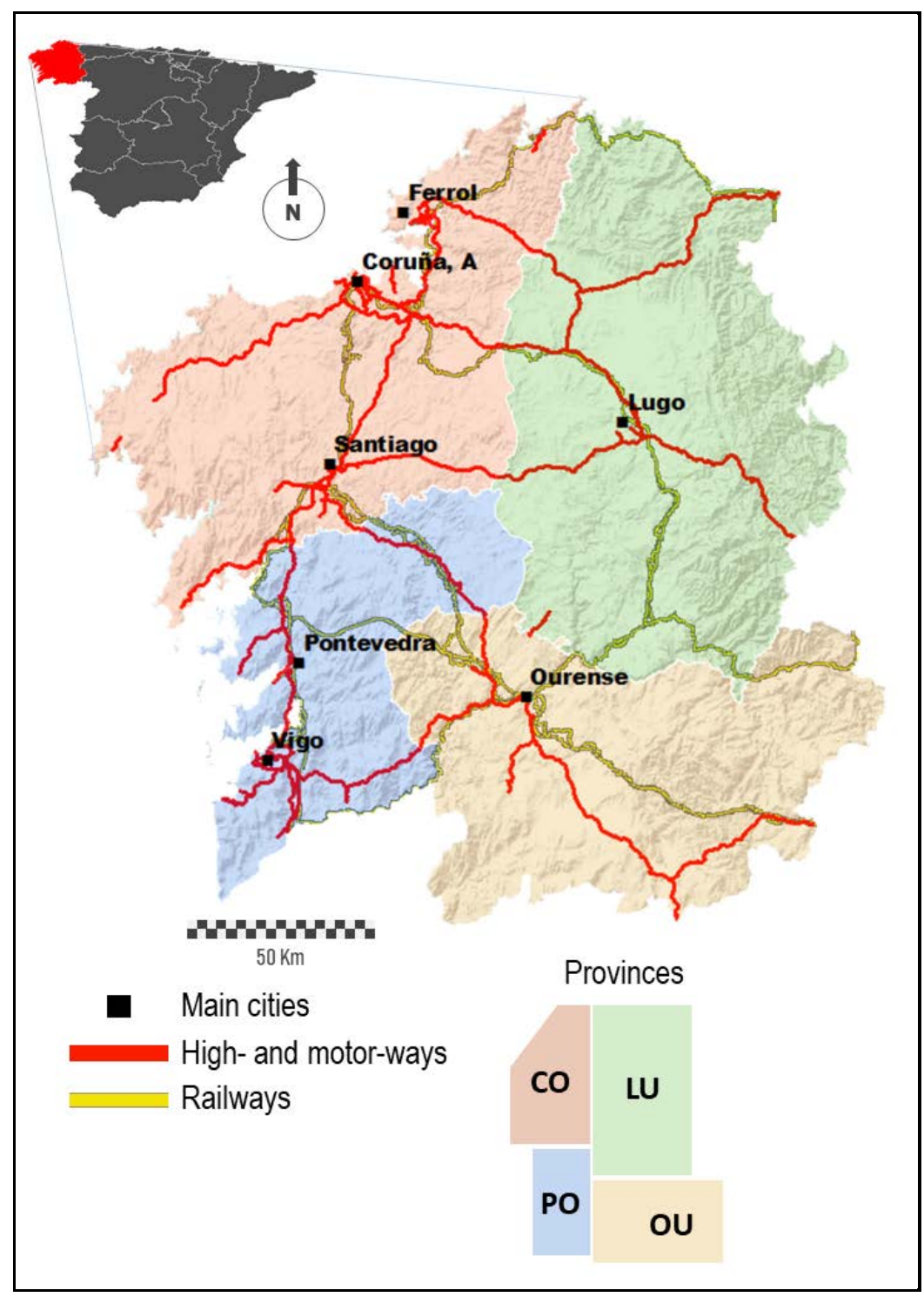

Note: The region of Galicia within Spain. The four background colours correspond to the four provinces labelled with their respective codes: CO (A Coruña), LU (Lugo), OU (Ourense) and PO (Pontevedra). We also represent the main road networks, i.e. motorways (red lines) and railways (yellow lines).

Source: authors' own elaboration

This region presents a dual population pattern. On the one hand, the most important cities concentrate around $80 \%$ of the population and $75 \%$ of the regional GDP (Pazos Otón, 2003), while a vast territory is rural and currently declining populations. This general pattern is evident at the provincial level, where the two western provinces present significant economic diversity and account for most of the population. This same demographic duality faces a very dynamic coastline with a depressed interior. Although the reality continues to be more complex, some exceptions arise in certain coastal sectors such as the case of A Costa da Morte, where the 
population dynamics are clearly regressive during the last decades (Balsa-Barreiro, 2013; BalsaBarreiro \& Landsperger, 2015).

This territorial structure determines the mobility patterns. On a regional scale, displacement flows to major cities and surrounding areas predominate. Internally, a significant number of head cities make up most of the non-urban territory. Most mobility flows in these predominantly rural areas cover greater distances compared to urban areas (Balsa-Barreiro, Morales \& Lois-González, 2021).

\section{The COVID-19 pandemic in Galicia}

This section is subdivided into three subsections. In the first (5.1) the relative incidence of the first wave in Galicia is contextualized. In the second (5.2) the most important territorial patterns related to the virus are analyzed. Finally (5.3) the evolution of mobility during the first months of the pandemic is represented.

\subsection{Contextualization}

The first case of COVID-19 in Spain was reported on January 31, 2020 in La Gomera, in the Canary archipelago. A few days later, on February 9, a second positive was detected in Palma de Mallorca. The first cases reported on the peninsula were registered in the last week of February in Madrid, Catalonia, the Basque Country, and Valencia. All these cases were initially imported from other countries, although community transmission within the country was already evident in early March. At the time the national authorities declared confinement (March 14, 2020), Spain had 6,332 cases and 193 deaths. The confinement decreed by the central government lasted 49 days, which were followed by a period of 40 days in which the restrictions were progressively eliminated until the end of the first wave, at the end of June. The balance of this first wave was, as of June 21, 246,504 cases and 28,313 deaths nationwide, although the real data was predictably much higher. According to the data published by the Daily Mortality Monitoring System (MoMo, 2020), the actual number of deaths from COVID-19 could be one third higher than those reported (Romero, 2020). The results of the first national seroprevalence study estimated that only 5\% of Spaniards had been infected with the virus during the first wave (Pollán et al., 2020), although showing great geographic variability, with a higher prevalence being observed in the surrounding environment. Madrid (> 10\%) and much less in coastal areas $(<3 \%)$. 
In the case of Galicia, the first official positive for COVID-19 was reported on March 4 and corresponded to a case imported from Madrid. Between the moment this case is notified, and the confinement decree implemented by the central government, only ten days elapse in which the virus circulates freely. Most of the cases reported during this period correspond mainly to imported cases from primary sources of infection and cases of community transmission within family circles, in addition to dependent personnel.

Figure 3. Incidence of COVID-19 in (a) Spain and (b) Galicia during the first wave

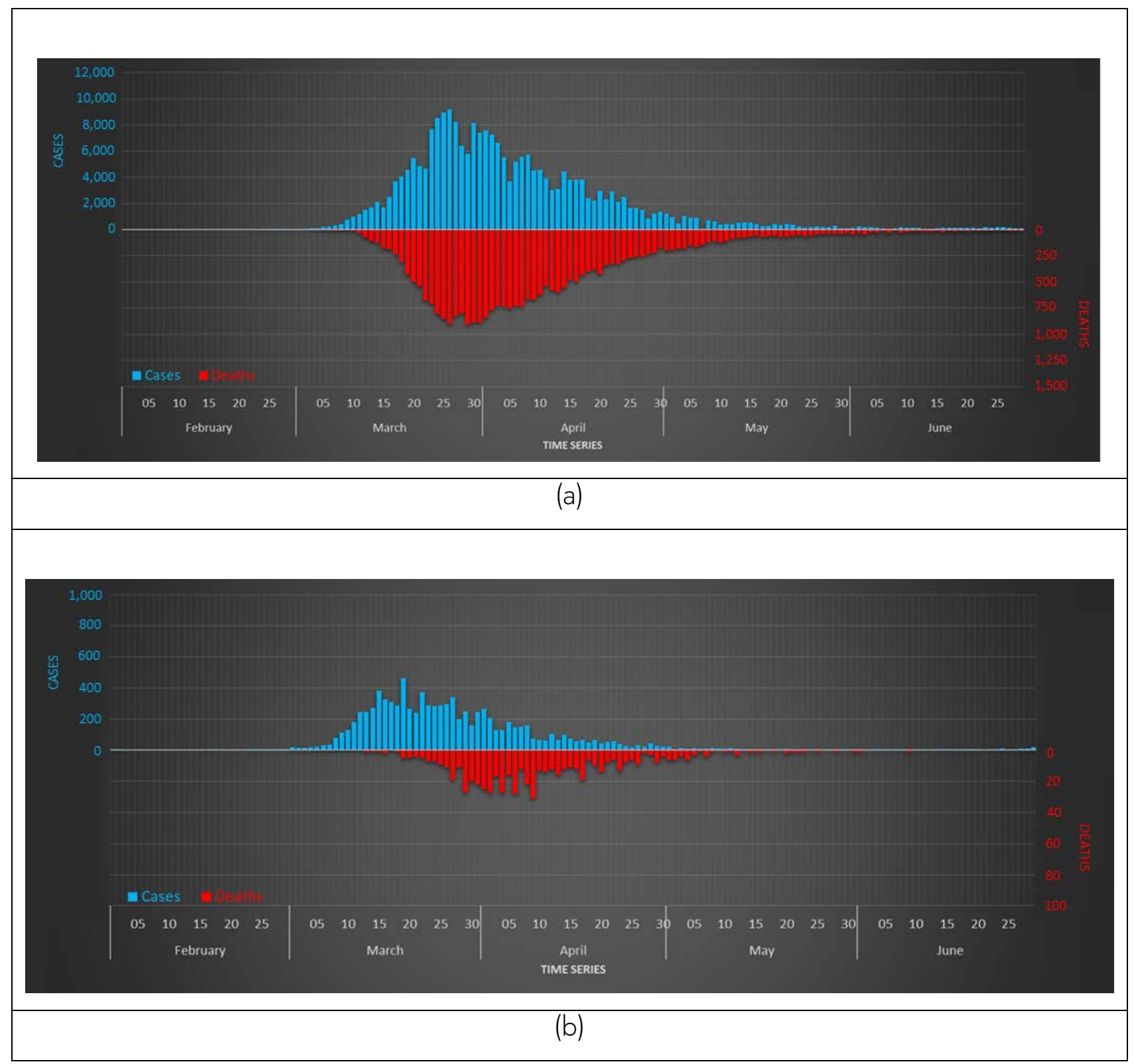

Source: authors' own elaboration from data

from National Epidemiology Center, Carlos III Health Institute (2020) 
In Galicia, the first wave left a total balance of 10,489 cases and 619 deaths. The seroprevalence study carried out during the first wave estimated that only $1.15 \%$ of the population had been infected, being in fact one of the least affected regions of Spain (Pollán et al., 2020). Comparatively, the fatality in Galicia was much lower than in the rest of Spain. As of June 30, 2020, Galicia concentrated $4.2 \%$ of cases and 2.2\% of deaths nationwide, a percentage considerably lower than its demographic weight (5.7\%). The accumulated number of cases per 100,000 inhabitants was 388.2, while that of deaths was 22.9. The fatality rate was 5.9 deaths per 100 reported cases. A comparative analysis between the incidence of the virus in Galicia and Spain is shown in Figure 3.

\subsection{Territorial analysis}

Most of the COVID-19 cases were concentrated in the more urban Galicia. One in two cases was registered in one of the seven main cities. Most were concentrated along the Atlantic Axis, which links five of the seven main cities. In fact, $36.9 \%$ of the cases were concentrated in these five cities alone. Outside this axis, the municipality of Ourense concentrated almost $10 \%$ of all cases, which in some way confirms the existence on the territory of a second axis of spread of the virus. Regarding urban municipalities, Lugo and Ferrol were the least affected with only 3.4\% and 2\% of the cases respectively (Figure 4a). A clearer view of the spread patterns of the virus can be seen in the heat map in Figure 4b). It clearly shows a high incidence axis (N-S) in the westernmost sector of the region, and a secondary axis with a SE-NW direction, with less continuity, which would link the urban region of Ourense with the Atlantic Axis. In general, the western and southern sectors of the region show incidence patterns much higher than the rest.

The aggregation of data by municipalities allows a clearer vision of the real incidence. Figure 5 shows how the incidence is concentrated in the most important cities, but also in a series of adjacent municipalities. These municipalities concentrate most of the industrial and logistics activity of the cities and a very important part of the residential land for many citizens who go daily to work in the nearest cities. These are areas with great economic diversity and high levels of human mobility, being the origin and destination of many daily trips. 


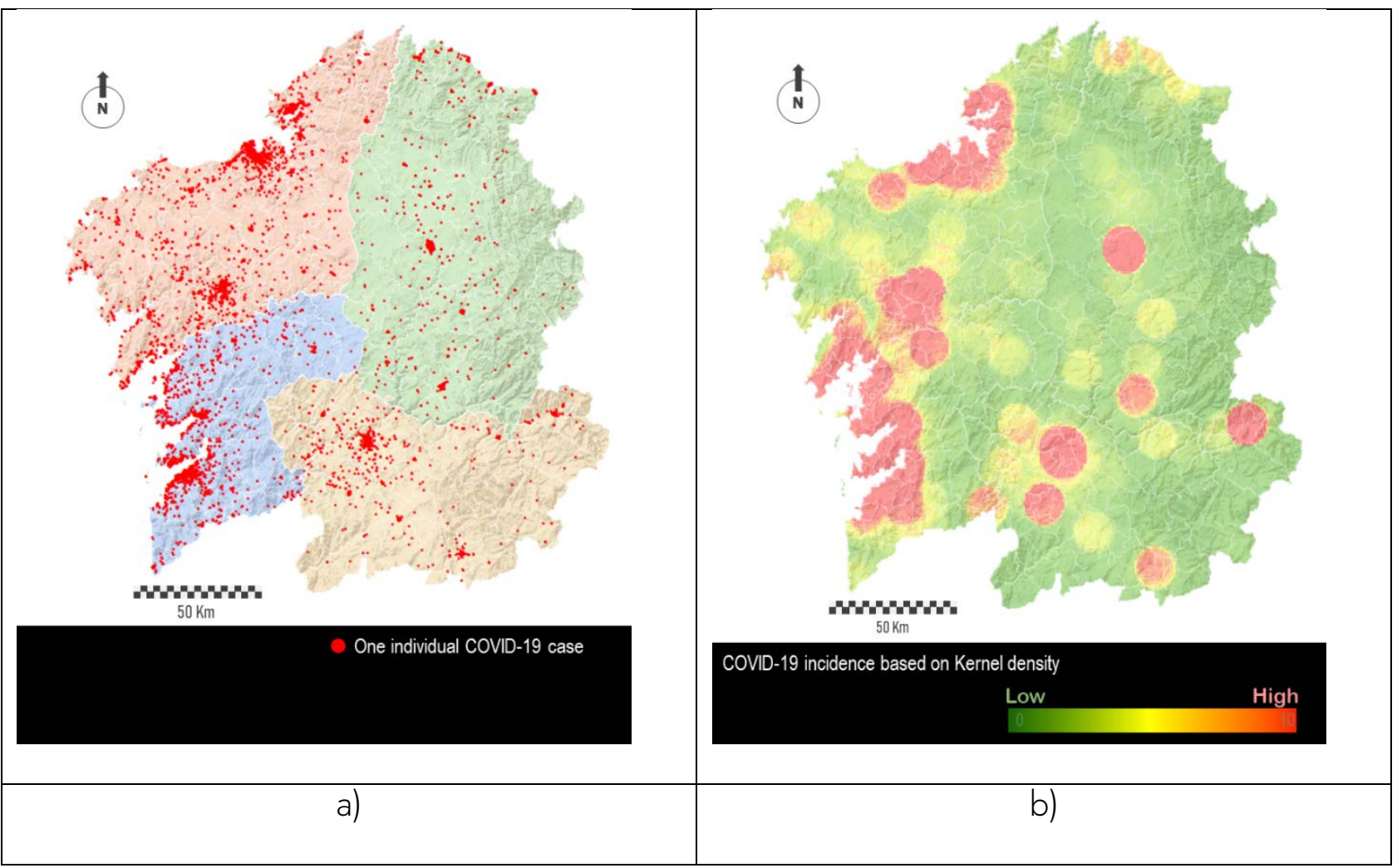

Key: (a) Mapping COVID-19 incidence across the region. Each node corresponds to an officially reported case. The geolocation of cases is based on the residence address of the infected person. (b) Heat map: the most affected areas in red.

Source: authors' own elaboration from data from Galician Health Service (2020)

A distribution of the municipalities by incidence of the virus in regular intervals (quartiles with the same number of cases) shows how practically all the municipalities in the provinces of A Coruña and Pontevedra fall into quartiles Q3 and Q4, shaded with redder tones. For its part, inland Galicia concentrates most of the least affected municipalities, shaded in yellow (quartile Q1). In addition, the set of municipalities shaded in gray present a special significance, which correspond to those municipalities in which no case was reported during the first wave. 
Figure 5. Territorial incidence of COVID-19 during the first wave

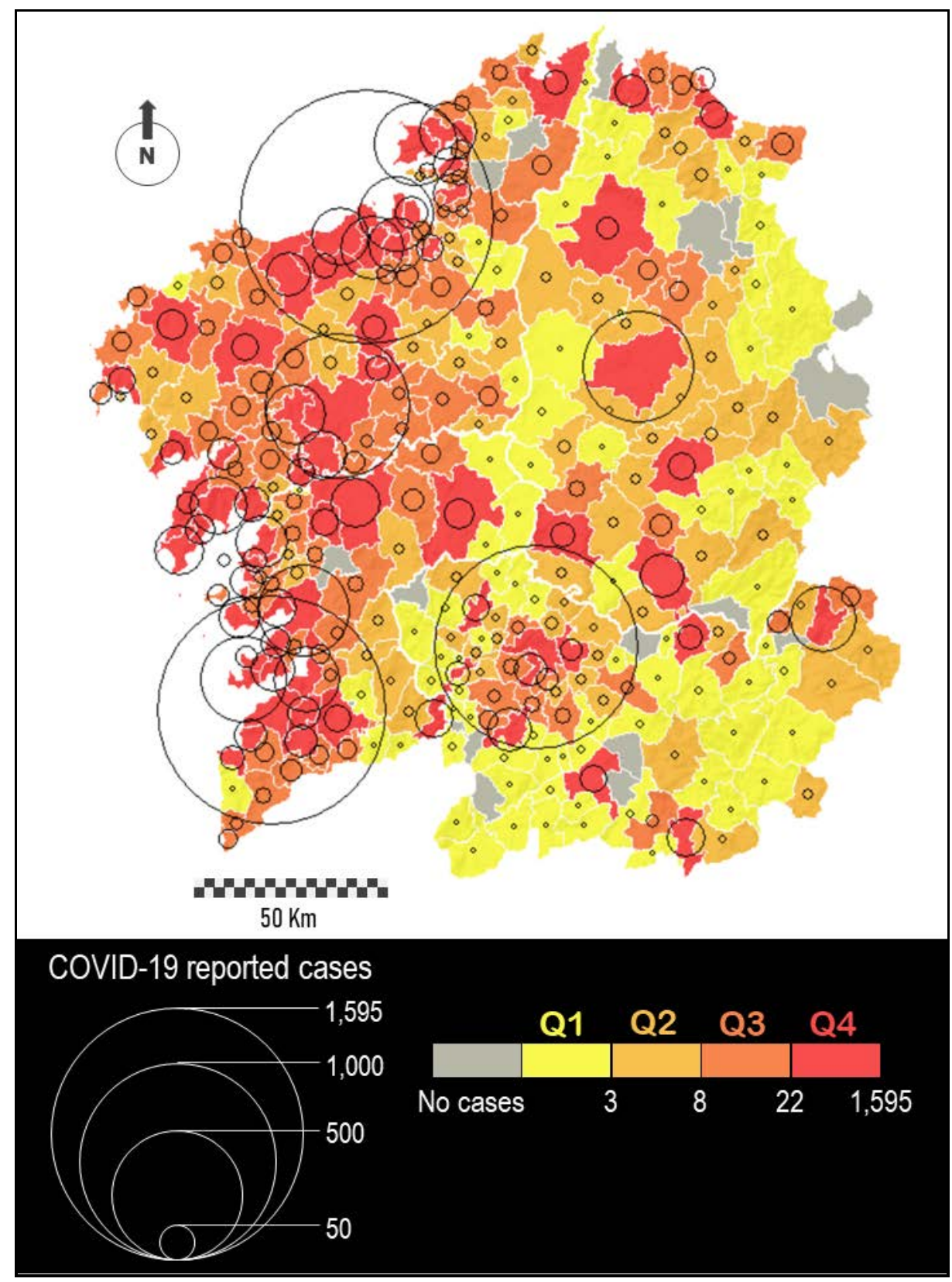

Note: Incidence of COVID-19 at a municipal scale: Total number of cases (node size) and distribution in regular intervals, i.e. four quartiles (background colour). Municipalities without COVID-19 cases are displayed in grey colour.

Source: own elaboration from data from Galician Health Service (2020)

The analysis of the relative incidence shows more heterogeneous patterns throughout the region. On the one hand, the density of cases per inhabitant (Figure 6.a) shows how the municipalities in the surroundings of the main cities show higher rates. This is clearly observed in municipalities around Santiago, A Coruña and Ourense. In the same way, it is observed that many interior municipalities present exceptionally high levels of density of cases per inhabitant in relative terms. 
The analysis of the density levels of cases per $\mathrm{km}^{2}$ (Figure 6.b) show a pattern very similar to the one initially proposed, where the western and southern sectors of the region tend to concentrate higher incidence levels.

Figure 6. Territorial incidence of COVID-19 during the first wave

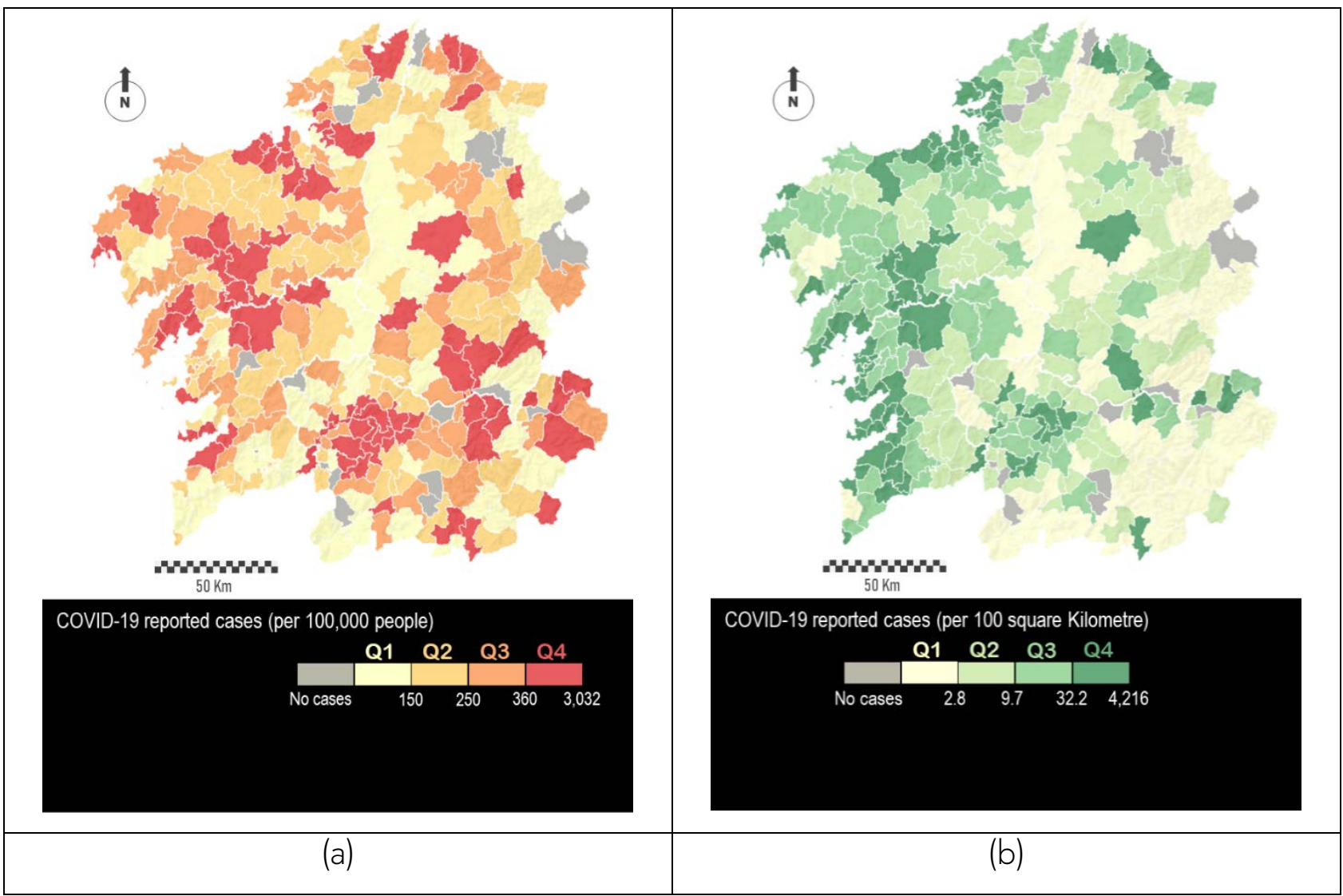

Key: (a) Density of cases by population - cases reported per 100,000 inhabitants. (b) Density of cases per area cases reported per 100 square Kilometre-. Data represented at the municipal level and classified at regular intervals.

Source: own elaboration from data from Galician Health Service (2020)

Figure 7a represents the 25 municipalities with the highest and lowest incidence of the virus. The warm tones indicate which were the most affected municipalities and the cold tones the least affected, without considering in this group all those municipalities free of COVID-19 represented in the preceding figures. These municipalities represented in light green have a single infected and are located for the most part in the provinces of Ourense and Lugo. For their part, the most affected municipalities are located for the most part along the Atlantic Axis. Figure 7b represents the incidence per 100,000 inhabitants, showing a much more heterogeneous territorial pattern, especially in the case of the province of Ourense, where many of the municipalities with the highest and lowest relative incidence are located. 
Figure 7. Territorial incidence of COVID-19 during the first wave

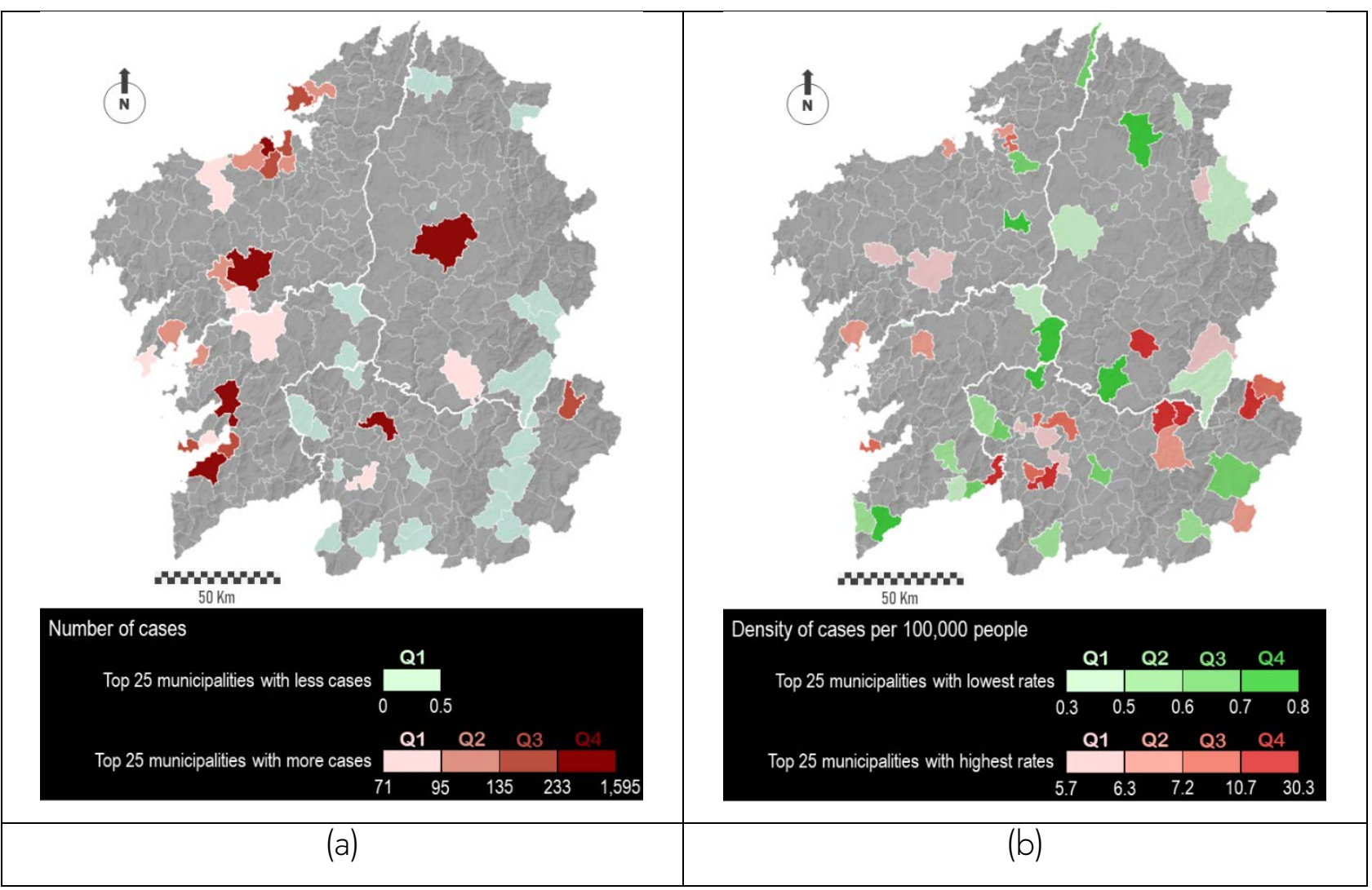

Note: Representation of the 25 most and least affected municipalities, except in this last group for the municipalities that did not register any cases, represented in the previous figures. (a) Number of registered cases. (b) Density of cases by population - cases reported per 100,000 inhabitants-. Data represented at the municipal level and classified at regular intervals.

Source: own elaboration from data from Galician Health Service (2020)

The two municipalities with the highest cumulative incidence during the first wave are the two most populated. A Coruña accounts for $14.7 \%$ of total cases and a cumulative incidence of 649.1 cases per 100,000 inhabitants. Vigo concentrates $12.1 \%$ of the cases and a cumulative incidence of 444.5 cases per 100,000 inhabitants. In them, the spread of the virus extends throughout the entire urban fabric (Figure 8). 
Figure 8. COVID cases registered in the two most populated municipalities in Galicia

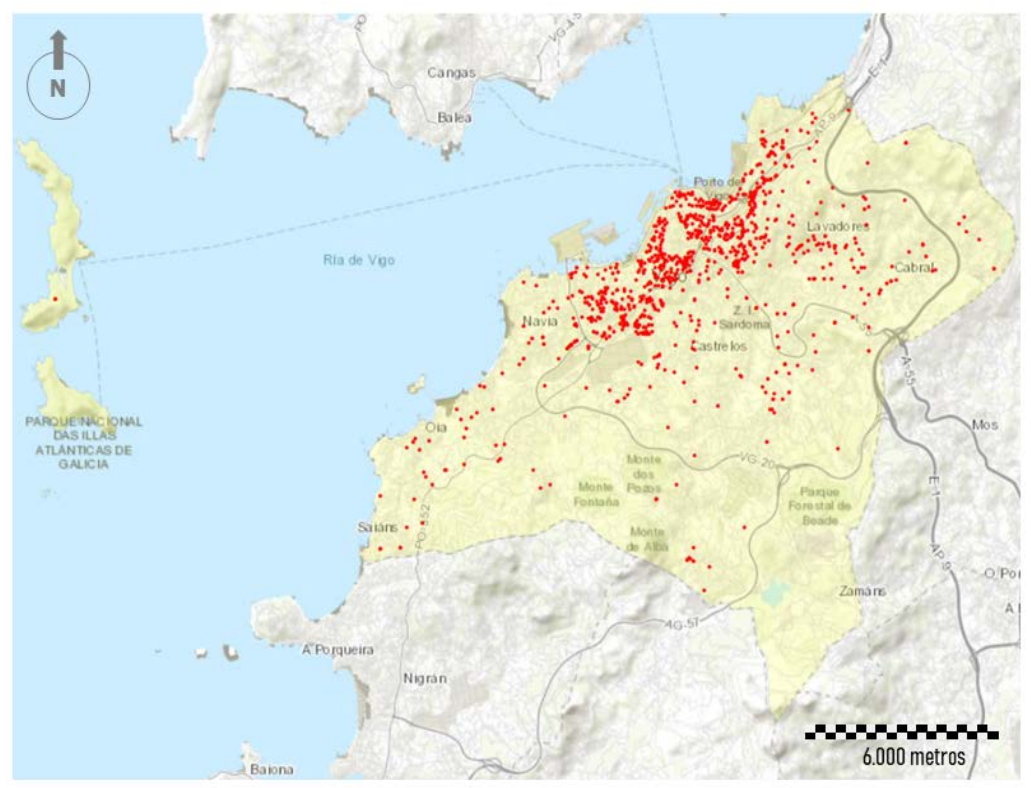

(a)

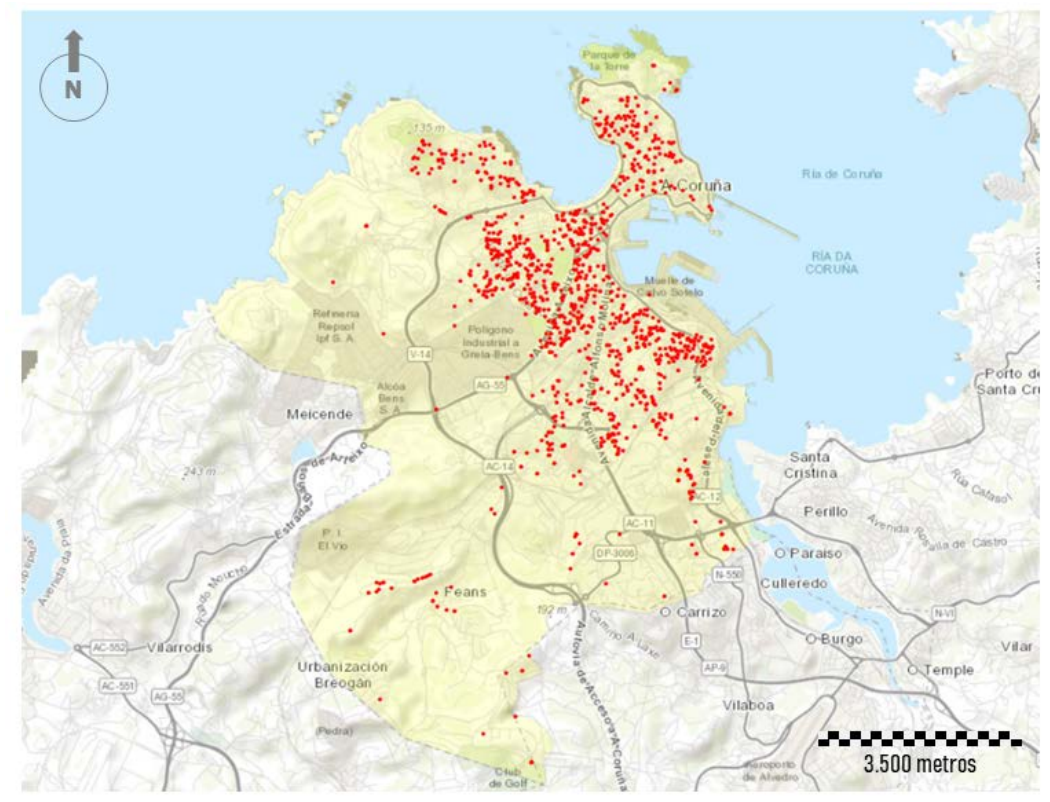

(b)

Note: (a) Vigo (b) A Coruña. Each reported case is represented by a red dot.

Source: own elaboration from data from Galician Health Service (2020)

The spread of the virus shows different patterns depending on the characteristics of the territory. Figure 9 shows the incidence in two urban centers located in different sectors of the region. The points are represented as a function of both the time of sampling (according to the month) and the need for hospital care at some point by the patients. 
Figure 9. Incidence of COVID-19 in three urban centers:

\section{Ourense and Vilagarcía de Arousa}

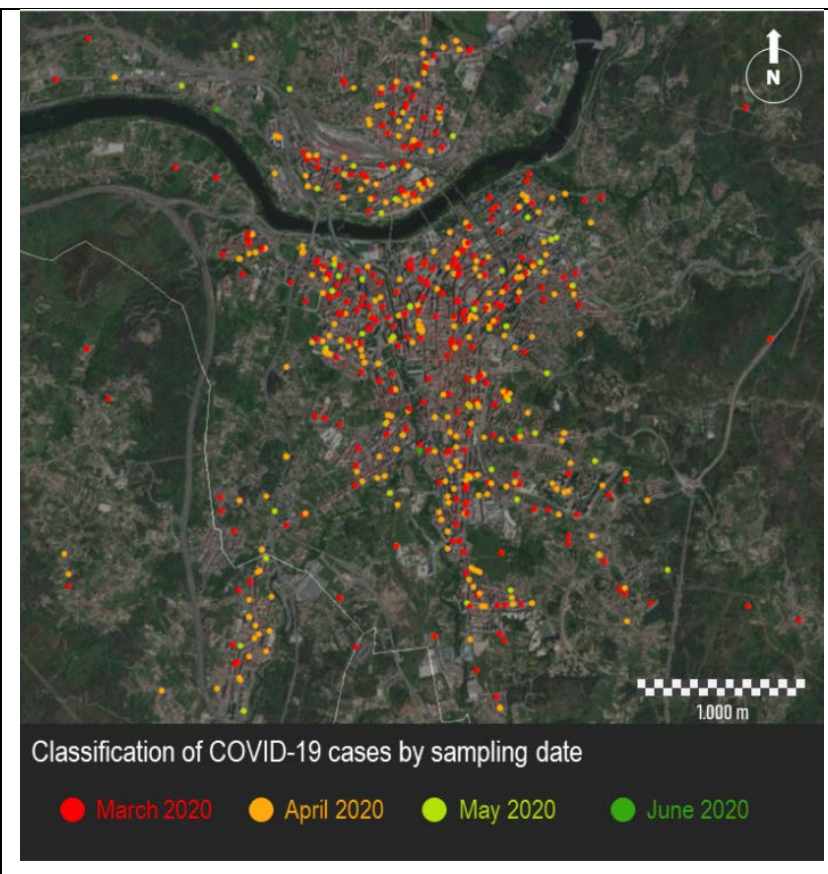

(a)
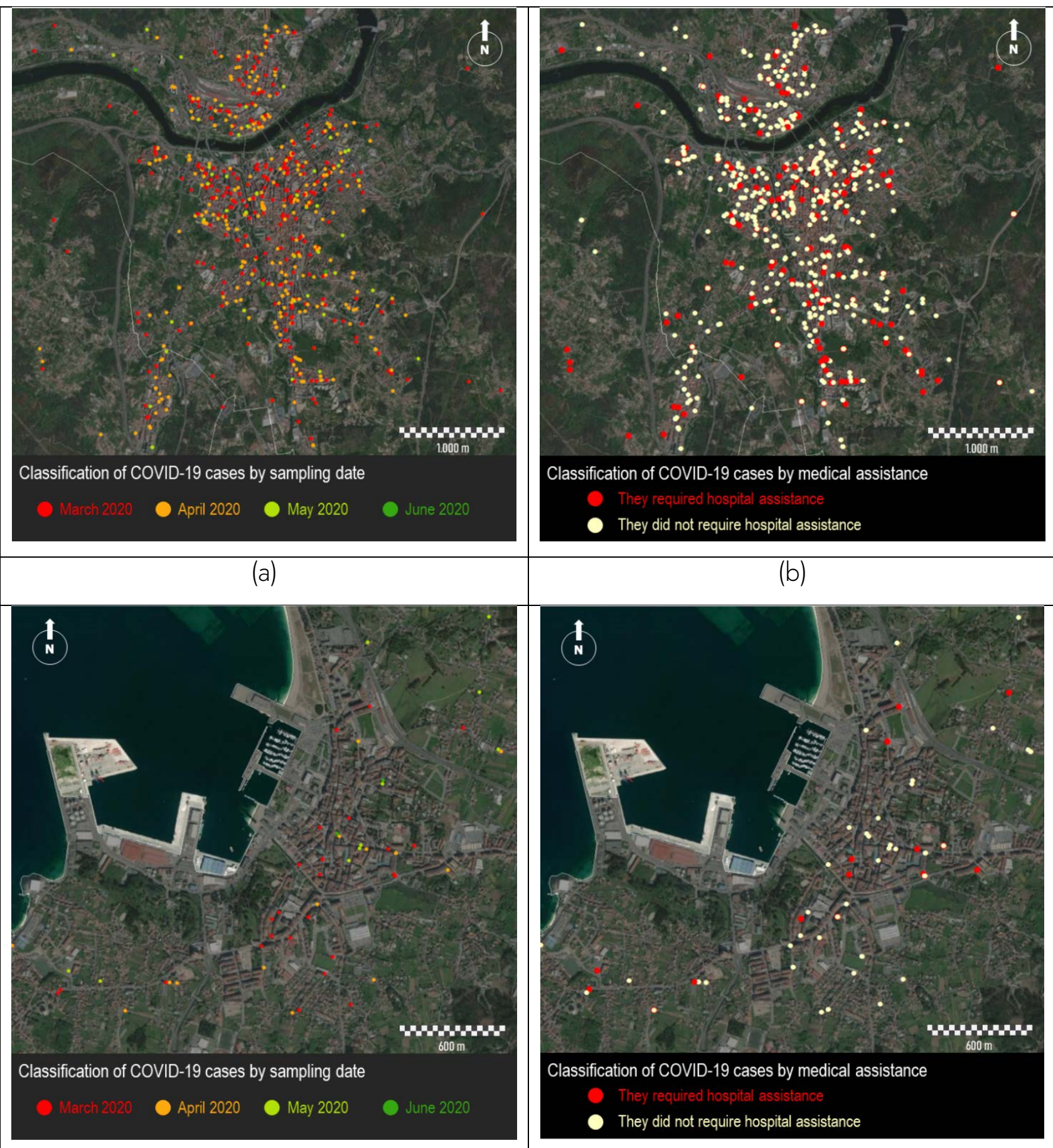

(b)

\section{(c)}

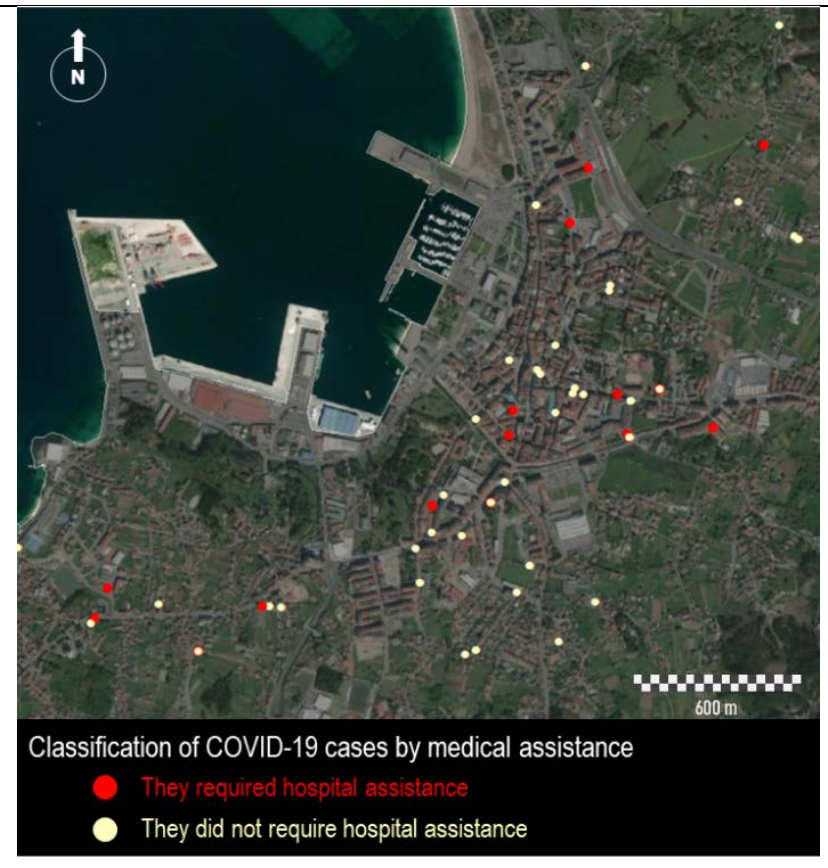

(d)

Note: (a, b) Ourense, (c, d) Vilagarcía de Arousa. On the left, distribution of the cases according to the sampling date. On the right, cases that required hospital care.

Source: own elaboration from data from Galician Health Service (2020) 


\subsection{Influence of mobility}

Most mobility dynamics have changed dramatically since the appearance of COVID-19 in midMarch 2020. In Spain, national authorities took over the entire country to control the virus. On March 14, they adopted a harsh lockdown with strict mobility restrictions and stay-at-home orders for everyone. Work activity was reduced to very few essential activities related to human care and the purchase of primary products. Between March 30 and April 9, only essential workers were able to travel for work. Most of the businesses related to non-essential activities, as well as cultural and religious facilities, were closed. With controlled management of the virus, this region was the first to ease mobility restrictions and return to pseudo-normality. It was carried out in four different phases. On May 4, some type of business and activities were authorized, mostly outdoors. Two weeks later, restaurants and some stores could be open, but with some partial restrictions on their capacity. Human mobility was limited in each province. On June 15, the region begins a "new normal" with no restrictions on mobility.

The first cases of virus detected in Galicia were imported from other regions of Spain, especially Madrid, which was at first the main source of infection. The transmission flows were determined by the land transport routes and the radial design of the infrastructures with Madrid (BalsaBarreiro et al., 2019). This road enters the SE sector of the region and crosses the cities of Ourense, Santiago and A Coruña. The significant difference in the levels of incidence of the virus in the two eastern provinces, which present similar demographic structures, would be explained from this radial road design and the relationship of the provincial capitals with the Atlantic Axis, being much more intense on the axis between Ourense and Vigo.

As the virus circulates within the system, the internal mobility flows and the territorial structure are decisive to understand the real spread of the virus. The temporal analysis of human mobility allows to verify the dynamic correlation between the virus and its territorial impact. From a territorial perspective, the highest rates of the virus were concentrated around the main cities, with high population densities. Furthermore, most of the industrial and logistics hubs are located in these same suburban areas. These are areas with significant economic diversity and high levels of human mobility, being the origin and destination of many daily trips. Figure 10 represents the change in mobility due to the impact of the virus and the implementation of restrictions by the central government. It is observed, as well as many of the spread patterns of the virus partially correspond to the predominant direction of the mobility fluxes presented. 
Figure 10. Mobility flows during the COVID-19 pandemic

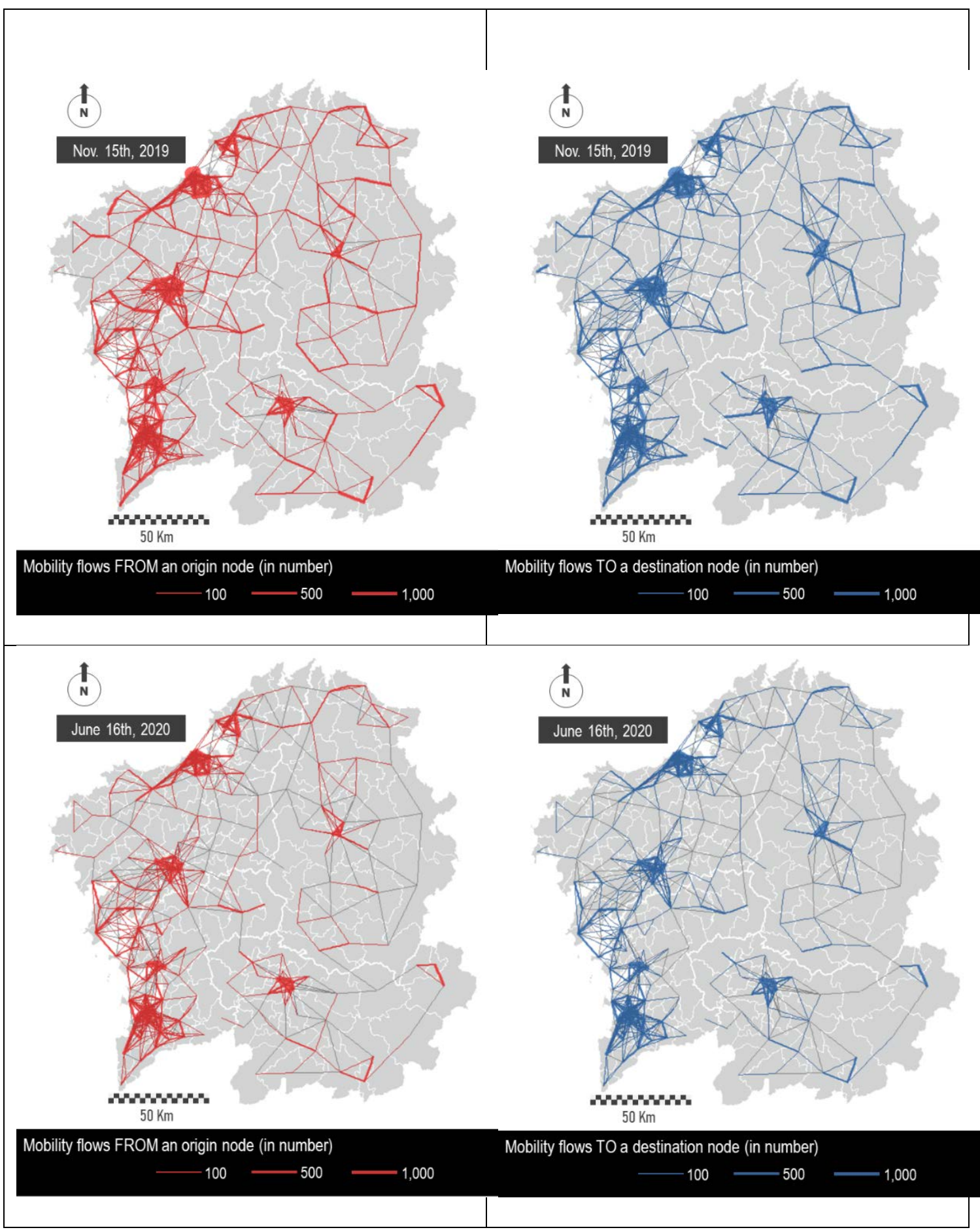

Note: In red the flows are represented considering a mobility area of origin. Flows are represented in blue considering a destination mobility area.

Source: own elaboration from data from INE (2020)

Some relevant territorial factors must be considered to understand the territorial complexity of the virus within this region. Among them, the spatial pattern of population distribution in this region could be of great significance. Traditionally, this spatial pattern was characterized by high 
fragmentation and dissemination throughout the territory. In fact, this region concentrates almost half of all the singular population entities located in Spain. In comparison, this rate is approximately 10 times higher than its demographic weight at the national level (INE, 2021). Although this model is still in force in rural Galicia, a very relevant process of increasing concentration is also observed in a specific group of municipalities with a small central urban nucleus, which has a considerable flow of displacements and, therefore, also had it infected (Balsa-Barreiro, Morales \& Lois-González, 2021).

\section{Conclusions}

Geospatial analysis is essential for the management of emergencies such as the current pandemic. Dashboards and web-based tools are being used to inform the population, in addition to traditional maps, while governments and authorities gain transparency in their public management. However, the importance of geospatial tools must go beyond the merely informative, becoming an essential tool for decision-making in near real time. It requires the willingness to share accurate and detailed information on the part of the responsible authorities. However, there are some concerns related to mapping this data that should be considered. Among them, to maintain people's privacy or avoid counterproductive effects such as generating unjustified false alarms in the population. Geospatial data plays a key role in any visualization strategy. For this, proper and responsible geodata management is required, adapting each map to specific audiences and purposes. In addition to optimal use of all the elements, the expert must always implement the most appropriate mapping strategies according to the objectives.

Throughout this document, we have presented some strategies to map detailed COVID-19 data on a specific territory such as Galicia. These data were geoprocessed with GIS tools. The maps were adapted to different objectives and scales.

The goal is to enhance the value of geospatial analysis for decision making. Data visualization must be clear and adapted to the audience, facilitating the integration of epidemiologists, health authorities and legislators to make the most appropriate decisions at any spatial scale.

In fact, some of the maps presented in this paper were provided to the competent authorities of the Government of Galicia to offer information on the territorial behavior of COVID-19 and help with its management. Although today, certain behaviors are considered confirmed, thanks to these maps we were able to detect the influence of nursing homes or industrial estates. 
Regardless of this information, in this paper we verify and confirm several Galician realities related to the pandemic in its origins:

1. The pandemic always arrived in Galicia a little later than in other areas of Spain.

2. The degree of incidence and impact of the pandemic was always lower in Galicia than in Spain.

3. In relation to the previous points, it can also be interpreted that the management from the Xunta de Galicia took the lead from the proposals that were made from the Autonomous Communities to the Central Government to coordinate the management of the pandemic.

4. COVID-19 presented a territorial distribution very similar to that of the socioeconomic variables throughout the Galician territory. There was a greater number of infected in urban areas and their areas of influence, the pandemic followed the route of the Atlantic Urban Axis.

5. While the municipal capitals that socio-economically structure the Galician rural territory had a lower incidence. To a large extent, due to not very high demographic and density values.

It must be emphasized that the maps and analyzes presented in this work are a sample of the importance of Geography and the study of the territory when there are pandemics such as COVID-19. In fact, part of what is exposed in this paper was presented throughout 2020 to the competent authorities related to the management of this health crisis in Galicia, becoming a real example of Applied Geography.

Acknowledgements: This paper was possible because from the Galician Innovation Agency (GAIN) of the Xunta de Galicia, an urgent public competitive call was offered during the month of March 2020, to the entire scientific community (public and private) to propose solutions for "fight" against COVID-19. The project "The risk mapping of COVID-19 in urban and rural areas of Galicia" was selected, which aimed to carry out a series of territorial analysis reports of the pandemic and give them to SERGAS. This project is the basis of this article. Therefore, these data were transmitted to us after the signing of a confidentiality commitment.

Authorship statement: The authors declare no conflict of interest. The participation of the authors in the article is as follows. Conceptualization, Á. Miramontes Carballada; methodology, Á. Miramontes Carballada and J. Balsa-Barreiro; software, J. Balsa-Barreiro; resources, Á. Miramontes Carballada; data cura-tion, Á. Miramontes Carballada; writing-original draft preparation, Á. Miramontes Carballada; writing-review and editing, Á. Miramontes Carballada and J. Balsa- 
Barreiro; visualization, J. Balsa-Barreiro; supervision, Á. Miramontes Carballada and J. BalsaBarreiro; project administration, Á. Miramontes Carballada. All authors have read and agreed to the published version of the manuscript. 


\section{References}

Arab-Mazar, Z, Sah, R., Rabaan, A.A., Dhama, K., \& Rodriguez-Morales, A.J. (2020). Mapping the incidence of the COVID-19 hotspot in Iran - implications for travellers Travel Medicine Infectious Disease, 34, 101630. https://doi.org/10.1016/j.tmaid.2020.101630

Balsa-Barreiro, J., \& Landsperger, S. (2015). A Costa da Morte (Galicia, España): un modelo demográfico antagónico al español. Análisis de su evolución demográfica en el siglo XXI. Journal of Iberian and Latin American Research, 2171), 63-

86. https://doi.org/10.1080/13260219.2015.1041198

Balsa-Barreiro, J. (2013). Insostenibilidad de modelos territoriales desde un punto de vista demográfico: El caso de Costa da Morte (Galicia, España). Papeles de población, 19(78), $167-$ 206. https: $/ /$ www. redalyc.org/articulo.oa?id $=11229719007$

Balsa-Barreiro, J., Ambühl, L., Menendez, M., \&Pentland A.S. (2019). Mapping time-varying accessibility and territorial cohesion with time-distorted maps. IEEE Access, 7, 4170241714. https://dspace. mit.edu/bitstream/handle/1721.1/134793/08675273.pdf? sequence $=$ 2\&isAllowed $=y$

Balsa-Barreiro, J., Morales, A., \& Lois-González, RC (2021). Mapping population dynamics at local scales using spatial networks. Complexity, 2021, ID 8632086. https://doi.org/10.1155/2021/8632086

BBC News (2020, March 30). Coronavirus: A visual Guide to the Pandemic. BBC news. https://www.bbc.co.uk/news/world-51235105

Boulos, K., \& Geraghty E.M (2020). Geographical tracking and mapping of coronavirus disease COVID-19/severe acute respiratory syndrome coronavirus 2 (SARS-CoV-2) epidemic and associated events around the world: how 21st century GIS technologies are supporting the global fight against outbreaks and epidemics. International Journal Health Geographics, 19, 8. https://doi.org/10.1186/s12942-020-00202-8

Buzai, G.D. (2020). De Wuhan a Luján. Evolución espacial del COVID-19. Posición, 3, 26838915. hitps://ri.unlu.edu.ar/xmlui/bitstream/handle/rediunlu/683/Buzai_Gustavo_COVID19. pdf? sequence $=1 \&$ isAllowed $=y$

Bynum, P., Raja R.A.I., \& Olbina, S. (2013). Building information modelling in support of sustainable design and construction. Journal of Construction Engineering and Management, 139, 24-34. http:://dx.doi.org/10.1061/(ASCE)CO.1943-7862.0000560 
Buckee, C.O., Balsari, S., Chan, J., Crosas, M., Dominici, F., Gasser, U., \& Lipsitch, M. (2020). Aggregated mobility data could help fight COVID-19. Science, 368(6487), 145146. https://doi.org/10.1126/science.abb8021

Carballada, A.M., \& Balsa-Barreiro, J. (2021) Geospatial Analysis and Mapping Strategies for Fine-Grained and Detailed COVID-19 Data with GIS. ISPRS International Journay Geo-Information, 10(9), 602. https://doi.org/10.3390/ijgi10090602

Cattarino, L., Rodriguez-Barraquer, I., Imai, N., Cummings, D.A.T., \& Ferguson, N.M. (2020). Mapping global variation in dengue 690 transmission intensity. Science Translational Medicine, 12(528). https://doi.org/10.1126/scitranslmed.aax4144

Centro Nacional de Epidemiología, Instituto de Salud Carlos III (2020). https://www.isciii.es/Paginas/Inicio.aspx

Chang, S.L., Harding, N., \& Zachreson, C. (2020). Modelling transmission and control of the COVID-19 pandemic in Australia. Nature Communications, 11, 5710. https://doi.org/10.1038/s41467-020-19393-6

Chen, S., Li, Q., Gao, S., Kang, Y., \& Shi, X. (2020a). Mitigating COVID-19 outbreak via high testing capacity and strong transmission-intervention in the United States. medRxiv https://www. medrxiv.org/content/10.1101/2020.04.03.20052720v1

Chen, S., Zhang, Q., Lu, Y., Guo, Z.M., Zhang, X., Zhang, W.J., \& Lu, J.H. (2020b). Distribution of the COVID-19 epidemic and correlation with population emigration from Wuhan, China. Chinese Medical Journal, 10441050. https://dx.doi.org/10.1097\%2FCM9.0000000000000782

Cicalò, E., \& Valentino, M. (2019). Mapping and visualisation of health data. The contribution of the graphic sciences to medical re-626 search from New York yellow fever to China coronavirus. Disegnarecon, 12(23), 12-21. https://doi.org/10.20365/disegnarecon.23.2019.12

Dagnino, R., Weber, E.J., \& Panitz, L.M. (2020). Monitoramento do Coronavírus (Covid-19) nos municípios do Rio Grande do Sul, Brasil. SocArXiv. https://doi.org/10.31235/osf.io/3uqn5 Deka, M.A., \& Morshed N. (2018). Mapping disease transmission risk of Nipah virus in South and Southeast Asia. Tropical Medicine and Infectious Disease, 3(2), 57. https://doi.org/10.3390/tropicalmed3020057 
De Kadt J., Gotz G., Hamann C., Maree G., Parker A., \& Gauteng City-Region Observatory; (2020). Mapping Vulnerability to COVID-19 in Gauteng. GCRO Map of the Month https://gcro.ac.za/outputs/map-of-the-month/detail/mapping-vulnerability-to-covid-19/

Desjardins, M.R., Hohl, A., \& Delmelle, E.M. (2020). Rapid surveillance of COVID-19 in the United States using a prospective space-time scan statistic: detecting and evaluating emerging clusters. Applied Geography, 118(102202), $102-$ 202. https://doi.org/10.1016/j.apgeog.2020.102202

Dong, E., Du, H., \& Gardner, L. (2020). An interactive web-based dashboard to track COVID-19 in real time. Lancet Infectious Diseases, 20, 533-534. https://doi.org/10.1016/S14733099(20)30120-1

Dudley, J. (2008). Public Health and Epidemiological Considerations for Avian Influenza Risk Mapping and Risk Assessment. Ecology and Society, 13(2). http://www.ecologyandsociety.org/vol13/iss2/art21/

Franch-Pardo, I., Napoletano, B.M., Rosete-Verges F., \& Billa L. (2020). Spatial analysis and GIS in the study of COVID-19. A review. The Science of the Total Environment. http://doi.org/10.1016/j.scitotenv.2020.140033
Gesler,
W.
$\&$
Kearns,
R.
(2002).

Culture/Place/Health. https://doi.org/10.4324/9780203996317

Gibson, L., \& Rush, D. (2020). Novel coronavirus in Cape Town informal settlements: feasibility of using informal dwelling outlines to identify high risk areas for COVID-19 transmission from a social distancing perspective. JMIR Public Health Surveillance, 6(2), e18844. https://doi.org/10.2196/18844

Giuliani, D., Dickson, M.M., Espa, G., \& Santi, F. (2020). Modelling and predicting the spatiotemporal spread of COVID-19 in Italy. BMC Infectious Disease, 20(700). https://doi.org/10.1186/s12879-020-05415-7

Graham, H. (2000). Understanding health inequalities. Open University Press.

Gross, B., Zheng, Z., Liu, S., Chen, X., Sela, A., Li, J., \& Havlin, S. (2020). Spatio-temporal propagation of COVID-19 pandemics. MedRxiv https://doi.org/10.1101/2020.03.23.20041517 
Guan W.J., Ni Z.Y., Hu Y., Liang W.H., Ou C.Q., He J.X., \& Du B. (2020). Clinical characteristics of coronavirus disease 2019 in China. New England Journal of Medicine, 382(18):1708-1720. https://doi.org/10.1056/NEJMoa2002032

Huang H., Wang Y., Wang Z., Liang Z., Qu S., Ma S., \& Liu X. (2020). Epidemic Features and Control of 2019 Novel Coronavirus Pneumonia in Wenzhou, China (3/3/2020). http://dx.doi.org/10.2139/ssrn.3550007

National Institute of Statistics (2021). [Website] https://www.ine.es

Kearns, R., \& Moon, G. (2002). From medical to health geography: novelty, place and theory after a decade of change. Progress Human Geography, 26(5), 605 625. http://citeseerx.ist.psu.edu/viewdoc/download?doi=10.1.1.137.3695\&rep=rep1\&type=p df

Koch, T. (2005). Cartographies of Disease: Maps, Mapping, and Medicine. ESRI Press.

Kuupiel, D., Adu, K.M., Bawontuo, V., Adogboba, D.A., Drain, P.K., Moshabela, M., \& Mashamba Thompson, T.P. (2020). Geographical accessibility to glucose-6-phosphate dioxygenase deficiency point-of-care testing for antenatal care in Ghana. Diagnostics, 10(4), 229. https://dx.doi.org/10.3390\%2Fdiagnostics10040229

Lee, J.G., \& Kang, M. (2015). Geospatial big data: challenges and opportunities. Big Data Research, 2(2), 74-81 https://doi.org/10.1016/j.bdr.2015.01.003

Lenzen, M., Li, M., Malik, A., Pomponi, F., Sun, Y., Wiedmann, T., Faturay, F., Fry, J., Gallego, B., Geschke, A., Gómez-Paredes, J., Kanemoto, K., Kenway, S., Nansai, K., Prokopenko, M., Wakiyama, T., Wang, Y., \& Yousefzadeh, M. (2020). Global socio-economic losses and environmental gains from the Coronavirus pandemic. PLOS ONE, 15, 1.13. https://doi.org/10.1371/journal.pone.0235654

Lois-González, R. (2004). A model of Spanish-Portuguese urban growth: the Atlantic axis. Dela, (21), 281-294. https://doi.org/10.4312/dela.21.281-294

Lyseen, A. K., Nøhr, C., Sørensen, E. M., Gudes, O., Geraghty, E. M., Shaw, N. T., BivonaTellez, C., \& IMIA Health GIS Working Group (2014). A Review and Framework for Categorizing Current Research and Development in Health Related Geographical Information Systems (GIS) Studies. Yearbook of medical informatics, 9(1), 110-124. https://doi.org/10.15265/IY-2014$\underline{0008}$ 
Meade, M.S. (2014). Medical geography. In The Wiley Blackwell Encyclopedia of Health, Illness, Behavior, and Society (pp. 1375-1381). https://doi.org/10.1002/9781118410868.wbehibs204 Messina, J., Kraemer, M.U., Brady, O.J., Pigott, D.M., Shearer, F.M., Weiss, D.J., Golding, N., Ruktanonchai, C.W., Gething, P.W., Cohn, E., Brownstein, J.S., Khan, K., Tatem, A.J., Jaenisch, T., Murray, C.J., Marinho, F., Scott, T.W., \& Hay, S.I. (2016). Mapping global environmental 695 suitability for Zika virus. Elife, 19(5),e15272. https://doi.org/10.7554/eLife.15272

Messina, J., Brady, O., \& Pigott, D. (2014). A global compendium of human dengue virus occurrence. Sciencie Data 1, 140004. https://doi.org/10.1038/sdata.2014.4

MoMo dashboard (n.d.). Instituto de Salud Carlos III (Spain). https://momo.isciii.es/public/momo/dashboard/momo_dash-738 board.html

National Health Commission (NHC) of the People's Republic of China (2020). NHC daily reports. http://www.nhc.gov.cn/yjb/pzhgli/new_list.shtml

Orea, L., \& Álvarez. I. C. (2020). How Effective Has the Spanish Lockdown Been to Battle COVID19? A Spatial Analysis of the Coronavirus Propagation across Provinces (Working Paper). FEDEA, Universidad de Oviedo. https://documentos.fedea.net/pubs/dt/2020/dt2020-03.pdf

Pattison, W.D. (1964) The four traditions of geography. Journal Geography, 63, 211216. https://doi.org/10.1080/00221346408985265

Pazos Otón, M. (2003). El estudio geográfico de la movilidad: un análisis histórico-evolutivo. In Xeográfic (pp. 101-119). Universidade de Santiago de Compostela.

Pham, Q., Nguyen, D.C., Huynh-The, T., Hwang W., \& Pathirana, P.N. (2020). Artificial Intelligence (AI) and Big Data for Coronavirus (COVID-19) Pandemic: A Survey on the State-of-theArts. IEEE Access, 8, 130820-130839. https://doi.org/10.1109/ACCESS.2020.3009328

Pigott, D.M., Golding, N., Mylne, A., Huang, Z., Henry, A.J., Weiss, D.J., Brady, O.J., Kraemer, M.U., Smith, D.L., Moyes, C.L., Bhatt, S., Gething, P.W., Horby, P.W., Bogoch, I.I., Brownstein, J.S., Mekaru, S.R., Tatem, A.J., Khan, K., \& Hay, S.I. (2014). Mapping the zoonotic niche of Ebola virus disease in Africa. Elife, 3, e04395. https://doi.org/10.7554/eLife.04395

Pollán, M., Pérez-Gómez, B., Pastor-Barriuso, R., Oteo, J., Hernán, M. A., Pérez-Olmeda, M., Sanmartín, J.L., Fernández-García, A., Cruz, I., Fernández de Larrea, N., Molina, M., RodríguezCabrera, F., Martín, M., Merino-Amador, P., Paniagua, J.L., Muñoz-Montalvo, J.F. Blanco, F., \& Yotti, R. (2020). Prevalence of SARS-CoV-2 in Spain (ENE-COVID): a nationwide, population- 
based seroepidemiological study. The Lancet, 396(10250), 535-

544. https://doi.org/10.1016/S0140-6736(20)31483-5

Rezaei, M., Nouri, A.A., Park, G.S., \& Kim, D.H. (2020). Application of geographic information system in monitoring and detecting the COVID-19 outbreak Iran Journal Public Health, 49, 114116. https://doi.org/10.18502/ijph.v49iS1.3679

Rodriguez-Morales, A.J., Galindo-Marquez, M.L., García-Loaiza, C.J., Sabogal-Roman, J.A., Marin-Loaiza, S., Ayala, A.F., Lagos-Grisales, G.J., Lozada-Riascos, C.O., Parra-Valencia, E., Rojas-Palacios, J.H., López, E., López, P., \& Grobusch, M.P. (2017). Mapping Zika virus disease incidence in Valle del Cauca. Infection, 45(1), 93-102. https://doi.org/10.1007/s15010-016$\underline{0948-1}$

Romero JM. (2020). Los muertos de la pandemia en España: 44.868. El País. $\quad$ https://elpais.com/sociedad/2020-07-25/las-44868-muertes-de-la-pandemia-en$\underline{\text { espana.html }}$

Rosenkrantz, L., Schuurman, N., Bell, N., \& Amram, O., (2021). The need for GIScience in mapping COVID-19. Health \&lace, 67, 102389. https://doi.org/10.1016/j.healthplace.2020.102389

Rossman, H., Keshet, A., Shilo, S., Gavrieli, A., Bauman, T., Cohen, O., \& Segal, E. (2020). A framework for identifying regional outbreak and spread of COVID-19 from one-minute population-wide surveys. Nature Medicine, 26, 634-638. https://doi.org/10.1038/s41591-020$\underline{0857-9}$

Saha, A., Gupta, K., \& Patil, M. (2020). Monitoring and Epidemiological Trends of Coronavirus Disease (COVID-19) around the World. Osfpreprints. https://osf.io/2mwky

Santana, P. (2005). Geografias da Saúde e do Desenvolvimento. Evolução e Tendências em Portugal, Coimbra. Ed. Almedina.

Santana Juárez, M.V. (2020). COVID-19 en México: comportamiento espacio temporal y condicionantes socioespaciales, febrero y marzo de 2020. Posición, 3, 2683-8915.

Sarwar, S., Waheedab, R., Sarwar, S., \& Khand, A. (2020). COVID-19 challenges to Pakistan: is GIS analysis useful to draw solutions? Science Total Environment, https://doi.org/10.1016/j.scitotenv.2020.139089

Schnaiberg, A., \& Gould, K. (1994). Environment and Society: The Enduring Conflict. St. Martin's Press. 
Trias-Llimós, S., Alustiza, A., Prats, C., Tobias, A., \& Riffe, T. (2020). The need for detailed COVID-19 data in Spain, The Lancet Public Health, 5(11), e576. https://doi.org/10.1016/S2468-2667(20)30234-6

Smith, D., Lapedes, A., Jong, J.D., Bestebroer, T., Rimmelzwaan, G., Osterhaus, A., \& Fouchier, R. (2004). Mapping the Antigenic and Genetic Evolution of Influenza Virus. Science, 305, 371376.

Su, L., Hong, N., Zhou, X., He, J., Ma, Y., Jiang, H., Han, L., Chang, F., Shan, G., Zhu, W., \& Long, Y. (2020). Evaluation of the Secondary Transmission Pattern and Epidemic Prediction of COVID-19 in the Four Metropolitan Areas of China. Frontiers in medicine, 7, 171. https://doi.org/10.3389/fmed.2020.00171

Tang W, Liao H, Marley G, Wang Z, Cheng W, Wu D, Yu R. (2020). The Changing Patterns of Coronavirus Disease 2019 (COVID-19) in China: A Tempogeographic Analysis of the Severe Acute Respiratory Syndrome Coronavirus 2. Clinical Infectious Diseases, 71(15), 818824. https://doi.org/10.1093/cid/ciaa423

The Novel Coronavirus Pneumonia Emergency Response Epidemiology Team (2020). Vital Surveillances: The Epidemiological Characteristics of an Outbreak of 2019 Novel Coronavirus Diseases (COVID-19) - China, 2020. China CDC Weekly, 2(8), 113122. https://doi.org/10.46234/ccdcw2020.032

The Lancet Public Health, COVID-19 in Spain: a predictable storm?, The Lancet Public Health, 5(11), e568. https://doi.org/10.1016/S2468-2667(20)30239-5

Tobaiqy, M., Qashqary, M., Al-Dahery, S., Mujallad, A., Hershan, A. A., Kamal, M. A., \& Helmi, N. (2020). Therapeutic management of patients with COVID-19: a systematic review. Infection Prevention in Practice, 2(3), 100061. https://doi.org/10.1016/j.infpip.2020.100061

Turner, B.L. (2002). Contested identities: human-environment geography and disciplinary implications in a restructuring academy. Annals Association American Geographers, 92(1), 52-74.

Wang, C., Horby, P. W., Hayden, F. G., \& Gao, G. F. (2020). A novel coronavirus outbreak of global health concern. Lancet, 395, 470-473.

World Health Organization (2020a). Report of the WHO-China Joint Mission on Coronavirus Disease 2019 (COVID-19). https://www.who.int/docs/default-source/coronaviruse/who-chinajoint-mission-on-covid-19-final-report.pdf 
World Health Organization (2020b). WHO Director-General's opening remarks at the media briefing on COVID-19-11 March 2020. https://www.who.int/dg/speeches/detail/whodirector-general-s-opening-remarks-at-the-media-briefing-on-covid-19--11-march-2020

Wilkinson, R. (1996). Unhealthy socities: the afflictions of inequality. Routledge https://doi.org/10.1111/1467-9566.ep10938939

Xiong, Y., Wang, Y., Chen, F., \& Zhu, M. (2020). Spatial statistics and influencing factors of the novel coronavirus pneumonia 2019 epidemic in Hubei Province, China. International Journal of Environmental Research Public Health, 17(11), 3903. https://doi.org/10.3390/ijerph17113903

Zhang, X., Rao, H.X., Wu, Y., Huang, Y., \& Dai, H. (2020). Comparison of the spatiotemporal characteristics of the COVID-19 and SARS outbreaks in mainland China. BMC Infectious Diseases, 20, 805. https://doi.org/10.1186/s12879-020-05537-y

Zhou, C., Su, F., Pei, T., Zhang, A., Du, Y., Luo, B., \& Song, C. (2020). COVID-19: challenges to GIS with big data. Geography and Sustainability, 1(1), 77-

87. https://doi.org/10.1016/j.geosus.2020.03.005 